\title{
Business Simulation Games: Effective Teaching Tools Or Window Dressing?
}

John R. Tanner, University of Louisiana at Lafayette, USA

Geoffrey Stewart, University of Louisiana at Lafayette, USA

Michael W. Totaro, University of Louisiana at Lafayette, USA

Melissa Hargrave, University of Louisiana at Lafayette, USA

\begin{abstract}
Business simulations serve as learning platforms that stimulate the "gaming" interest of students, that provide a structured learning environment, and that should help manage the time resources of faculty. Simulations appear to provide a context where students feel learning can take place. However, faculty perception of simulation research is lacking. This study focuses on perceptions of management and marketing faculty in U.S. business schools. Both groups perceive simulations as useful teaching tools for their undergraduate courses; however, neither group views simulations as offering learning opportunities that are superior to traditional methodologies, such as case studies, service learning, or in-class discussions.
\end{abstract}

Keywords: Business Simulations; Gaming; Teaching; Undergraduate Business Students

\section{INTRODUCTION}

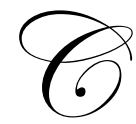

apturing the attention of undergraduate business students has never been more difficult than today's academic environment. As members of Generation Y, research shows that student attention spans are shorter, they desire interaction and stimulation, and they thrive in structured environments (Wilson \& Gerber, 2008). Student engagement has subsequently become more important than ever because students thrive in an environment where they are challenged. These students have lived their entire lives with technology that was not previously available. The development of video games, and the depth of involvement in "gaming," is not only a characteristic of this generation, but also an expectation of what is required to capture the attention and interest of today's student.

Based on the characteristics and preferences of this generation, it seems that experiential teaching methodologies would provide the requisite stimuli to engage students in the learning process. Student engagement has traditionally been successfully stimulated through experiential methodologies like internships, service learning, case studies, and group projects. While these methods have been shown to be effective (Raymond \& McNabb, 1993), they can be perceived as "the way we have always done things" or "standard fare in a dynamically changing environment" if faculty do not account for student dynamism and innovativeness in the project design. As with developing effective research designs, effective teaching practice requires an investment of the scarcest resource...time.

\section{RESEARCH PROBLEM}

Business simulations serve as learning platforms that stimulate the "gaming" interest of students, that provide a structured learning environment, and that should help manage the time resources of faculty. While introduced in 1956 by the American Management Association (Cohen \& Rhenman, 1961), simulations have grown considerably in popularity within business schools over the last 10 or so years. Research has shown that students perceive simulations as being: (1) engaging; (2) useful; (3) effective learning tools; and (4) effective in promoting teamwork (Lainema \& Lainema, 2007). Simulations appear to provide a context where students feel learning can take place. 
However, business simulation research is lacking on the perceptions of faculty. The literature is replete with studies that ask students to evaluate the impact of simulations on their own learning (de Freitas, 2006), but there is little insight into teacher perceptions of business simulation games as experiential teaching tools. This research study focused specifically on the perceptions of management and marketing faculty in U.S. business schools. The study was designed specifically to address the following research questions:

- $\quad$ Do faculty members agree with student evaluations of business simulation games as effective learning tools?

- Do faculty members believe simulations are more effective than traditional experiential methodologies?

- What value do faculty members receive from the incorporation of simulations in their teaching methods?

\section{LITERATURE REVIEW}

\section{Experiential Learning and Teaching Methodologies}

Anselmi and Frankel (2004) describe the Extended Buying Center Game (EBCG), an experiential learning exercise that integrates marketing concepts and theory with a particular emphasis on industry skills. Moreover, EBCG does so using an adaptive course design format. As a learning tool for students enrolled in a marketing course, EBCG focuses on: (1) organizational buying behavior; (2) buyer-seller interaction; and (3) marketing response. The EBCG structure offers students active learning by way of cooperative and competitive role-playing opportunities, individual and group written assignments and presentations, and verbal skill challenges. The authors also highlight the point that the use of EBCG may be extended beyond marketing courses to other business courses such as operations and purchasing, and management and negotiation.

Citing case studies as inadequate for student learning — due mainly to the absence of a direct, personal encounter with the events under study - McCarthy and McCarthy (2006) argue for mandatory experiential programs in all major areas within the business curriculum. Specifically, they: (1) investigate the theory behind experiential learning; (2) survey the role of experiential programs in the business curriculum; and (3) discuss the effects of integrating job shadowing into the curriculum of a regional university business course. Among the 68 respondents to a student survey, all found job shadowing as either helpful or very helpful. Concomitant with this is the fact that the next highest rating was for speeches in the class.

Xu and Yang (2010) study the factors that contribute to student learning by way of business simulation tools. Their results imply a positive impact on knowledge development in student groups from both social interaction and psychological safety. Additionally, the synergy from these causal elements allowed students to develop complex mental models.

\section{Simulations as Experiential Learning Tools}

Tonks (2005) describes a survey of the state of computer-based simulations in marketing education. Tonks's survey suggests that simulation use in marketing education is in fact in a mature phase, with very little likelihood of innovation. The conclusion by Tonks is somewhat pessimistic; specifically, such maturation in the area of simulation use may be generalized to other technology-based approaches in marketing education.

\section{Knowledge Application}

Léger (2006) proposes a simulation game approach for teaching Enterprise Resource Planning (ERP) concepts, whereby undergraduate IT students at an AACSB accredited school are expected to run their own (fictitious) business with a real-life ERP (e.g., mySAP ERP). Pedagogical objectives of this approach include the development of hands-on understanding of ERP concepts, opportunity for experiential benefits from enterprise integration, and the development of technical skills as regards the use of ERP software. 


\section{Student Experience}

Buzzetto-More and Bryant (2009) chronicle student perceptions of business simulations in a Strategic Management course at a predominantly minority-based institution located in the northeastern United States. A convenience sample of 138 senior business majors responded to an online survey, which included a mixture of multiple choice and 5-point Likert scale questions. Results suggest that these students felt that business simulations helped significantly in their understanding about how course concepts are applied to the real world. Moreover, these students believe that simulations inject greater enjoyment into the learning process, and that more simulations should be considered in a greater number of courses.

\section{Teamwork}

A study by Tompson (1995) compared the use of computer simulation for a group project with more traditional group rates. Ratings for each type were done on ten performance-related criteria. Results of the study indicate that computer simulations seem to be more effective in terms of preparing students for group-based projects than traditional ones.

The importance of increasing involvement and realism of marketing education for students and student teams is discussed by Lamont (2001). Specifically, team learning theory is developed, which is integrated with a model of the learning stages for interactive simulations. A principal contribution of the paper by Lamont is a set of guidelines that purport to ensure relevant educational experiences for students, student teams, and marketing educators.

\section{Student Interest}

Students' perceptions of computer-based simulation team dynamics and their individual fondness for (or dislike of) simulations and simulation performance were examined by Anderson (2005). The results of this study show that student team cohesion and student team independence strongly influenced their perceptions of the use of computer-based simulations. An important aspect of their results is that of student outcomes desired by the instructor and how best to achieve those outcomes in terms of team formation as per simulation learning.

\section{Instructional Outcomes}

\section{Learning Outcomes}

A study by Gorrell (1992) focused on identification of the processes associated with student learning by way of computer simulations. While the simulations were not done in business courses (these were, in fact, used in education courses), the simulations employed in this study were intended to facilitate students' learning of behavior analysis as they relate to resolution of classroom management problems. The relevant issue from Gorrell's study is that simulations offer the student opportunities for increased practice with tasks at hand, the result of which is significantly increasing performance by the student.

Romme (2003) examines learning outcomes from computer-based simulations in undergraduate and graduate business programs. Specifically, the effects of computer-based simulations on student learning, educational approach, and course design are discussed. Results suggest that effective combinations of course readings, class discussions, presentations, and simulations lead to deeper and accelerated learning.

\section{Methodological Comparisons}

Results of a study by Michlitsch and Sidle (2002), where faculty at U.S. business schools were surveyed in order to investigate the frequency of use and perceived effectiveness of eight methods used in assessment of student learning, showed that, across business disciplines, case studies were used most frequently. They suggest that this is consistent with high perceptions of the effectiveness of case studies for student learning in business courses. Additionally, roughly $70 \%$ of respondents say that they use computer simulation assignments. Surprisingly, $73 \%$ of respondents claim that such assignments have "moderate-to-strong effectiveness." 
Goorha and Mohan (2010) sought to enhance understanding about the learning preferences of business students, the objective of which was to then identify course contents and teaching strategies that would support such learning preferences. Their results were partitioned into a number of subcategories, all of which were distributed among three main categories; namely: (1) student learning style; (2) student learning preference; and (3) student preferences on teaching style. In the student learning style category, $67.8 \%$ of student respondents reported that lectures were at least somewhat important, as compared with the importance of both audio-visual recordings and mathematics and statistics. In the student learning preference category, $75.9 \%$ viewed favorably toward increasing technical content in class, as compared to lesser percentages that held favorable views toward preparatory courses in mathematics, practice problems, and seminars and workshops. Finally, in the student preferences on teaching style category, $79.2 \%$ held favorable views toward the lecturer speaking about his or her research occasionally, in contrast to $54.4 \%$ who preferred theoretical content over applied content.

\section{Benefits to the Instructor}

Maher and Hughner (2005) studied the impact on students' perceptions and ratings of an actual client-based project versus a simulation-based client project for a marketing project. Additionally, their study examined student perceptions of learning. Results of their study suggest that student find both formats effective in terms of learning about real-world marketing issues. Moreover, both formats reflected favorable project evaluations and enhanced perceptions of learning by students.

Students' perceptions of a purely experiential (i.e., simulation-based) learning course in an MBA Marketing curriculum are described by Li, Greenberg, and Nicholls (2007). Their survey-based study involved a convenience sample of 588 students at a regional university. Findings from the study show that students perceived the simulation approach as a viable alternative to the lecture-based approach.

Jager (2007) attempts to provide of formalization of the four P's - product, price, placement, and promotion - for the development of a social simulation model intended for consumer markets. The main contribution of this paper is that suggestions are made for the construction of an experimental design based on the formalization of the four P's, as well as the use of different forms of empirical data.

As shown in the extant literature, students view simulations are effective experiential learning tools and effective tools for building teamwork and decision making skills. Additionally, previous research shows that simulations can improve learning outcomes and that today's students are seeking technical content in class. While these findings appear to help explain the rise of simulation games in business schools, they are primarily based on student perceptions. Our study focuses on faculty and examines both Marketing and Management faculty perceptions of computer-based simulations in their respective disciplines. This study evaluates faculty along dimensions that were viewed as being important to students and then, based on the literature, evaluates simulation learning outcomes, compares simulations to other teaching methods, and assesses the benefits of simulations to the instructor. Additionally, perceptions between the two faculty groups are compared to identify areas of significant statistical differences.

\section{METHODOLOGY}

The purpose of this research was to learn more about how simulations as an academic learning tool were perceived by marketing and management faculty across the nation. Based on the findings of Mitchell (2004), the research team developed a survey instrument that translated themes from student comments about simulations into items that could be presented to faculty. The themes identified by Mitchell (2004) included:

- $\quad$ Theme 1 - the simulation helped students understand and integrate previous business course concepts in ways that enable them to apply the concepts in future.

- $\quad$ Theme 2 - the simulations provide a real-world, hands-on experience in strategic thinking and dealing with competition and uncertainty.

- $\quad$ Theme 3 - the simulation provided more experience in team work and working with others.

- $\quad$ Theme 4 - the simulation was interesting and fun. 
Items within each theme were adapted to incorporate an instructor's perspective rather than a student's perspective. The survey instrument is presented in the Appendix.

In an effort to determine these perceptions an electronic questionnaire was sent to a random sample of 1586 marketing management faculty in the United States. Usable returns were received from 107 respondents, a response rate of at least 6.7 percent, which is within the acceptable response rate according to a widely-cited source on survey research (Alreck \& Settle, 2004).

Tables 1 through 6 show the results of significance tests between the Marketing and Management faculty, with respect to their attitudes/perceptions of Likert-type statements in the survey instrument. These Likert statements have been divided into several areas or themes which can be applied to simulation. Each table covers these themes, and the themes are in the titles of the table.

\section{FINDINGS}

Table 1 shows the results of significance tests between the attitudes and/or perceptions of these two faculty groups on statements pertaining to knowledge application, as related to the use of simulations in the classroom in certain courses. As the table shows, both marketing and management faculty exhibited the same level of agreement that simulations were helpful in applying the concepts taught in their respective disciplines. However, when asked if they thought simulations created a learning context to students, would students to be more willing to open their minds to, and accept, the course subject matter and to apply the lessons learned in the course in which simulations were used, management faculty respondents had a significantly stronger level of agreement than did marketing faculty respondents.

Table 1: Knowledge Application

\begin{tabular}{|c|c|c|c|c|}
\hline \multirow{2}{*}{$\begin{array}{c}\text { Likert } \\
\text { Statements }\end{array}$} & \multicolumn{2}{|c|}{ Mean Responses* } & \multirow[b]{2}{*}{ t-stat } & \multirow[b]{2}{*}{ p-value } \\
\hline & MKTG & MGMT & & \\
\hline \multicolumn{5}{|l|}{$\begin{array}{l}\text { The simulation helps students understand and integrate previous business } \\
\text { course concepts in ways that enable them to apply the concepts in future. } \\
\text { Simulations... }\end{array}$} \\
\hline 1. ... are helpful in applying concepts that are taught in my discipline. & 3.82 & 4.08 & -1.29 & .202 \\
\hline $\begin{array}{l}\text { 2. ...are effective in creating a learning context where students are willing to } \\
\text { open their minds to the course subject matter. }\end{array}$ & 3.60 & 4.10 & -2.56 & $.012 * *$ \\
\hline 3. ....are effective in getting students to apply lessons learned in my course. & 3.69 & 4.10 & -2.10 & $.038 * *$ \\
\hline 4. ...make learning more enjoyable. & 3.84 & 4.08 & -1.38 & .170 \\
\hline 5. ...make learning the material in my course more enjoyable. & 3.55 & 3.98 & -2.35 & $.021 * *$ \\
\hline 6. ...make the material in my course easier to understand. & 3.36 & 3.62 & -1.25 & .212 \\
\hline $\begin{array}{l}\text { 7. ...provide an educational experience where students can learn about inter- } \\
\text { functional coordination within a business }\end{array}$ & 3.84 & 4.25 & -2.37 & $.019 * *$ \\
\hline 8. ...enable students to experience competition within a marketplace. & 3.96 & 4.23 & -1.42 & .158 \\
\hline
\end{tabular}

$* 1$ = Strongly Disagree; 2 = Disagree; 3 = Neither Agree nor Disagree; 4 = Agree; 5 = Strongly Agree

$* *$ Significant at .05 or less level

Both groups also agreed to the same extent that simulations made learning more enjoyable overall, and especially the material being taught in the course using them. But, when asked if they thought simulations made learning the material in their respective courses more enjoyable, management faculty respondents again exhibited a significantly stronger level of agreement than the marketing faculty. The same results were observed when the respondents were asked to state their level of agreement with the statement that simulations provided an educational experience wherein students about the cross-functional coordination within a business; i.e., the management faculty respondents had a significantly stronger level of agreement than the marketing faculty respondents.

Likewise, both faculty groups agreed, to the same extent, that the use of simulations in a course allowed students to experience the competition, which is frequently-observed in the marketplace. Moreover, both faculty 
groups agreed that simulations allowed them to structure their course outlines around simulation schedules. Lastly, both faculty groups again exhibited the same level of agreement that they could integrate simulation schedules into their respective course outlines with some ease.

Table 2 shows the results of significance tests between the attitudes/perceptions of marketing and management faculty with respect to the effect of simulations on student experiences. As can be seen in the table, both faculty groups had the same level of agreement with the statement that simulations allow students to think for themselves and that simulations also give students an opportunity to apply theories learned in the classroom to realworld situations. Both faculty groups also agreed, to the same extent, that simulations gave students experience in decision-making. These same two groups also agreed that simulations gave students a good feel for running a business against aggressive competitors; however, when asked if they thought simulations provided students with the experience of running a business, the marketing faculty respondents had a significantly higher level of agreement than did the management faculty respondents.

Lastly, both faculty groups had the same level of agreement that uncertainty about the future, and uncertainty about competition forces students to make a careful analysis of strategic decisions before actuating them.

Table 2: Student Experience

\begin{tabular}{|c|c|c|c|c|}
\hline \multirow{2}{*}{$\begin{array}{c}\text { Likert } \\
\text { Statements }\end{array}$} & \multicolumn{2}{|c|}{ Mean Responses* } & \multirow[b]{2}{*}{ t-stat } & \multirow[b]{2}{*}{ p-value } \\
\hline & MKTG & MGMT & & \\
\hline \multicolumn{5}{|l|}{$\begin{array}{l}\text { Simulations provide a real-world, hands-on experience in strategic thinking } \\
\text { and dealing with competition and uncertainty. } \\
\text { Simulations... }\end{array}$} \\
\hline 1. ...allow students to think for themselves. & 3.65 & 3.79 & -0.82 & 415 \\
\hline $\begin{array}{l}\text { 2. ..provide an opportunity for students to apply theory in real-world } \\
\text { situations. }\end{array}$ & 3.53 & 4.81 & -1.35 & .181 \\
\hline 3. ...provide students with decision-making experience. & 4.24 & 4.48 & -1.85 & .067 \\
\hline $\begin{array}{l}\text { 4. ..provide a tangible feel for running a major operation against aggressive } \\
\text { competitors. }\end{array}$ & 3.35 & 3.69 & -1.59 & .115 \\
\hline $\begin{array}{l}\text { 5. ...expose students to situations where the application of lessons (decisions) } \\
\text { make a difference in company performance. }\end{array}$ & 3.89 & 4.12 & -131 & .194 \\
\hline ...provide students with the experience of running a business. & 2.85 & 3.29 & -2.07 & $.041 * *$ \\
\hline $\begin{array}{l}\text { 7. Within simulations, the uncertainty about the future forces students to } \\
\text { carefully analyze strategic decisions. }\end{array}$ & 3.64 & 3.73 & -0.57 & .570 \\
\hline $\begin{array}{l}\text { 8. Within simulations, the uncertainty about competition forces students to } \\
\text { carefully analyzes strategic decisions. }\end{array}$ & 3.73 & 3.71 & 0.95 & .925 \\
\hline
\end{tabular}

*1 = Strongly Disagree; 2 = Disagree; 3 = Neither Agree nor Disagree; 4 = Agree; 5 = Strongly Agree

**Significant at .05 or less level

Table 3 shows the results of significance tests for a difference between the attitudes/perceptions of marketing faculty and management faculty with respect to the effect of teamwork involved in simulations. The results of the significance tests seem to show the perceived importance of simulations by both marketing and management faculty respondents since both groups had basically the same level of significance with all five of the Likert statements related to teamwork,

Both groups of faculty respondents agreed, to the same extent, that simulations allow students to work in groups; in fact, there are many cases whereby group work on these types of course requirements is usually required by the professor. Both faculty groups also had the same level of agreement that simulations force students to use their time wisely, and that decision deadlines in simulations effectively aid students to do a good job of organizing their efforts. Along these same lines, both faculty groups agreed to the same extent that simulations are effective in integrating learning with both team-building activities, and in integrating competition with learning. 
Table 3: Team Work

\begin{tabular}{|c|c|c|c|c|}
\hline \multirow{2}{*}{$\begin{array}{c}\text { Likert } \\
\text { Statements }\end{array}$} & \multicolumn{2}{|c|}{ Mean Responses* } & \multirow[b]{2}{*}{ t-stat } & \multirow[b]{2}{*}{ p-value } \\
\hline & MKTG & MGMT & & \\
\hline $\begin{array}{l}\text { The simulation provided more experience in team work and working with } \\
\text { others. } \\
\text { Simulations... }\end{array}$ & & & & \\
\hline 1. ...allow students to work in groups. & 4.18 & 4.25 & -0.50 & .617 \\
\hline 2. ...force students to manage their time wisely. & 3.47 & 3.48 & -0.05 & .964 \\
\hline 3. ...effectively integrate learning with team-building activities.. & 3.31 & 3.60 & -1.64 & .105 \\
\hline 4. ...effectively integrate competition with learning. & 3.75 & 3.85 & -0.62 & .540 \\
\hline $\begin{array}{l}\text { 5. The decision deadlines are effective in helping students organize their } \\
\text { efforts. }\end{array}$ & 3.80 & 3.85 & -0.32 & .752 \\
\hline
\end{tabular}

$* 1=$ Strongly Disagree; 2 = Disagree; 3 = Neither Agree nor Disagree; 4 = Agree; $5=$ Strongly Agree

$* *$ Significant at .05 or less level

Table 4 shows the results of significance tests between the attitudes of marketing and management faculty with respect to their perceptions of the effect of simulations on student interest and, to a certain lesser degree, faculty interest as well. As can be seen from the table, once again, both marketing and management faculty respondents had the same levels of agreement with all Likert statements related to the effect of simulations on student interest and, to a certain extent, faculty interest. Both groups felt that students believed simulations were exciting and were more fun than courses in which the main process involved traditional classroom lectures, and that simulations would help students to understand where good decision in simulations would lead their companies. Also with respect to faculty interest, both marketing and management faculty respondents had the same level of agreement with the statements that simulations were exciting to them as instructors and that simulations were more fun than delivering traditional lectures.

Table 4: Student Interest

\begin{tabular}{|c|c|c|c|c|}
\hline \multirow[b]{2}{*}{ Likert Statements } & \multicolumn{2}{|c|}{ Mean Responses* } & \multirow[b]{2}{*}{ t-stat } & \multirow[b]{2}{*}{ p-value } \\
\hline & MKTG & MGMT & & \\
\hline \multicolumn{5}{|l|}{ The simulation was interesting and fun. } \\
\hline 1. Students feel that simulations are exciting. & 3.`58 & 3.71 & -0.82 & 413 \\
\hline $\begin{array}{l}\text { 2. Students feel that simulations are more fun than participating in traditional } \\
\text { lecture. }\end{array}$ & 3.82 & 3.92 & -0.64 & .525 \\
\hline 3. As an instructor, I feel that simulations are exciting. & 3.40 & 3.75 & -1.62 & .108 \\
\hline $\begin{array}{l}\text { 4. As an instructor, I feel that simulations are more fun than participating in } \\
\text { traditional lecture. . }\end{array}$ & 3.45 & 3.67 & -1.00 & .318 \\
\hline $\begin{array}{l}\text { 5. Students feel that simulation games are effective in helping them to see } \\
\text { where decisions will lead their company }\end{array}$ & 3.49 & 3.77 & -1.64 & .104 \\
\hline
\end{tabular}

*1 = Strongly Disagree; 2 = Disagree; 3 = Neither Agree nor Disagree; 4 = Agree; 5 = Strongly Agree

**Significant at .05 or less level

Table 5 shows the results of significance tests between marketing and management faculty respondents with respect to their perceptions of student learning outcomes and of project methodologies, as both these factors relate to the use of simulations in their classrooms.

As we see, both groups agreed that the iterative decision processes associated with simulations allows students to learn from previous decisions, but management faculty exhibited a significantly stronger level of agreement. Both groups agree, however, that simulations create competition among students and that simulations empower students, to a certain extent, to take control over the learning process. In terms of whether simulations allow students to have greater control of the learning process, both groups neither agreed nor disagreed. 
Table 5: Learning Outcomes

\begin{tabular}{|c|c|c|c|c|}
\hline \multirow[b]{2}{*}{$\begin{array}{c}\text { Likert } \\
\text { Statements }\end{array}$} & \multicolumn{2}{|c|}{ Mean Responses* } & \multirow[b]{2}{*}{ t-stat } & \multirow[b]{2}{*}{ p-value } \\
\hline & $\begin{array}{l}\text { MKTG } \\
\text { Faculty }\end{array}$ & $\begin{array}{l}\text { MGMT } \\
\text { Faculty }\end{array}$ & & \\
\hline $\begin{array}{l}\text { 1. Over the course of a simulation, the iterative decision process enables } \\
\text { students to learn from previous decisions. }\end{array}$ & 3.80 & 4.13 & -2.35 & $.021 * *$ \\
\hline Simulations create competition amongst students. & 4.16 & 4.13 & -0.20 & .840 \\
\hline 3. Simulations empower students to take control of the learning process. & 3.27 & 3.27 & 0.02 & .985 \\
\hline
\end{tabular}

$* 1$ = Strongly Disagree; 2 = Disagree; 3 = Neither Agree nor Disagree; 4 = Agree; 5 = Strongly Agree

$* *$ Significant at .05 or less level

With respect to methodologies (Table 6), both faculty groups tended to approach neutrality when asked if they thought simulations were more effective than case studies, service learning initiatives, or in-class discussion. However, when asked if they thought that simulations were more effective than traditional research papers, as compared to other project methodologies, both groups tended to approach agreement.

Table 7 shows the results of significance tests between the marketing and management faculty respondents with respect to their perceptions about benefits to the instructor, as such benefits pertain to the use of simulation games in their classes. As the table shows, both marketing and management faculty respondents agreed, to the same extent, that simulations established a context for discussion in class. They both showed the same level of disagreement with the statement that simulations reduced their preparation time for class.

Table 6: Theme 6 - Methodological Comparisons

\begin{tabular}{|c|c|c|c|c|}
\hline \multicolumn{1}{|c|}{$\begin{array}{c}\text { Likert } \\
\text { Statements }\end{array}$} & \multicolumn{2}{|c|}{ Mean Responses* } & \\
\cline { 3 - 5 } & $\begin{array}{c}\text { MKTG } \\
\text { Faculty }\end{array}$ & $\begin{array}{c}\text { MGMT } \\
\text { Faculty }\end{array}$ & t-stat & p-value \\
\hline $\begin{array}{l}\text { Compared to other project methodologies, simulations are more effective } \\
\text { than case studies. }\end{array}$ & 2.80 & 3.02 & -1.13 & .261 \\
\hline $\begin{array}{l}\text { Compared to other project methodologies, simulations are more effective } \\
\text { than service learning initiatives. }\end{array}$ & 2.75 & 3.00 & -1.22 & .226 \\
\hline $\begin{array}{l}\text { Compared to other project methodologies, simulations are more effective } \\
\text { than traditional research papers. }\end{array}$ & 3.35 & 3.71 & -1.82 & .071 \\
\hline $4 . \quad \begin{array}{l}\text { Compared to other project methodologies, simulations are more effective } \\
\text { than in-class discussion. }\end{array}$ & 2.87 & 3.10 & -1.07 & .288 \\
\hline
\end{tabular}

*1 = Strongly Disagree; 2 = Disagree; 3 = Neither Agree nor Disagree; 4 = Agree; 5 = Strongly Agree

**Significant at .05 or less level

Table 7: Theme 7 - Benefits to the Instructor

\begin{tabular}{|c|c|c|c|c|}
\hline \multirow[b]{2}{*}{$\begin{array}{c}\text { Likert } \\
\text { Statements }\end{array}$} & \multicolumn{2}{|c|}{ Mean Responses* } & \multirow[b]{2}{*}{ t-stat } & \multirow[b]{2}{*}{ p-value } \\
\hline & $\begin{array}{l}\text { MKTG } \\
\text { Faculty }\end{array}$ & $\begin{array}{l}\text { MGMT } \\
\text { Faculty }\end{array}$ & & \\
\hline 1. Simulations establish a context for class discussions. & 3.78 & 3.98 & -1.13 & .212 \\
\hline 2. Given the structure of the game, simulations reduce my preparation time. & 2.31 & 2.15 & 0.82 & .414 \\
\hline 3. Simulations improve the learning environment of my classroom. & 3.53 & 3.75 & -1.42 & .160 \\
\hline 4. Simulations effectively engage the minds of my students. & 3.60 & 3.79 & -1.25 & .214 \\
\hline $\begin{array}{l}\text { 5. Simulations positively influence the engagement of students on other course- } \\
\text { related activities. }\end{array}$ & 3.20 & 3.37 & -1.06 & .293 \\
\hline 6. I feel that simulation games make me a more effective instructor. & 3.18 & 3.37 & -0.83 & .410 \\
\hline 7. Simulation games have inspired me to be more creative in class. & 2.89 & 3.00 & -0.53 & .601 \\
\hline 8. Simulation games help me to connect with my students. & 3.15 & 3.31 & -0.82 & .414 \\
\hline
\end{tabular}

$* 1=$ Strongly Disagree; 2 = Disagree; 3 = Neither Agree nor Disagree; 4 = Agree; $5=$ Strongly Agree

$* *$ Significant at .05 or less level 
Both faculty groups agreed that simulations improved the learning environment of their classrooms, engaged the minds of their students, and positively influenced student engagement on other course-related activities. Both faculty groups also had the same level of agreement that simulation games made them a more effective instructor, but they both approached neutrality in their response to the statement that simulation games inspired them to be more creative in class. However, both groups agreed to the same extent that simulation games helped them to connect with their students, which would perhaps be viewed as a very positive finding.

\section{IMPLICATIONS}

When reviewing the perceptions of faculty, it is quite evident that faculty feel simulations (1) helped students understand and integrate previous business course concepts, (2) provided a real-world experience in strategic thinking and dealing with competition, (3), provided more experience in team work, and (4) are interesting and fun. These findings are congruent with previous research on student perceptions of simulations. This study used student perceptions to develop scales for the four themes mentioned above and provides evidence that business professors agree with students that simulations are effective in stimulating concept applications and that they create an enriching learning experience.

One of the most intriguing areas of this study involved the comparison of simulations to other teaching methodologies. While simulations are engaging, faculty do not believe they are holistically more effective than cases, service learning, and in-class discussions. A breakdown of the comparisons is as follows:

- $\quad$ Case Studies - While $44.5 \%$ of faculty neither agree nor disagree, $\underline{30.5} \%$ strongly disagree or disagree that simulations are more effective than cases studies. Only $25 \%$ of faculty agreed or strongly agreed that simulations were more effective than cases.

- $\quad$ Service Learning - While $42.2 \%$ of faculty neither agree nor disagree, $35.2 \%$ strongly disagree or disagree that simulations are more effective than service learning initiatives. Only $22.6 \%$ of faculty agreed or strongly agreed that simulations were more effective than cases.

- In-Class Discussion - While 37.5\% of faculty neither agree nor disagree, $32.8 \%$ strongly disagree or disagree that simulations are more effective than in-class discussions. Only $29.7 \%$ of faculty agreed or strongly agreed that simulations were more effective than cases.

- Relative to traditional research papers, $50.5 \%$ of faculty agreed or strongly agreed that simulations are more effective teaching methodologies.

Based on these results, it appears that the majority of faculty do not agree that simulations are more effective than case studies, service learning, or in-class discussions. While, evidence show many are undecided, there are more in disagreement than in agreement on all three comparisons. The only area where simulations appeared to garner strong support was in the comparison to traditional research papers. In reviewing these results, this could be because it is more descriptive in nature and does not incorporate active engagement in discussions and/or participation.

Simulations, unlike other methodologies, provide a structured environment that in theory should create some economies for instructors as they are used over an extended period of time. While, there was not clear agreement that simulations improved one's efficiency, there was more agreement in the area of improving one's effectiveness. With respect to prep time, $60.6 \%$ of faculty strongly disagreed or disagreed that simulations reduce their prep time. In the area of effectiveness, $48.0 \%$ of faculty agreed or strongly agreed while only $22 \%$ disagreed or strongly disagreed that simulations made them more effective instructors.

An interesting implication of this research was that less than half of the faculty surveyed did not feel that simulations inspired them to be more creative or helped them connect with their students. Given the "gaming environment" in today's society, these findings are somewhat surprising since simulations are supposed to be cutting edge and an engaging learning environment for students. With respect to creativity, only $33.9 \%$ of faculty agreed or strongly agreed that simulations inspire them to be more creative in class. Similar results were found in the area of connecting with students were only $45.9 \%$ of faculty agreed or strongly agreed that simulations inspire them to be more creative in class. 


\section{FUTURE RESEARCH}

While this study shows that there is agreement amongst marketing and management faculty that simulations enrich the classroom in a number of ways, the findings also create several opportunities for future research. First, faculty shared similar perceptions of students with respect to the knowledge application, student experience, teamwork, and student interest. Future research could expand these findings assessing the "novelty" or "sexiness" of simulation games in today's classrooms. Methodologies like case studies and research papers have existed much longer than simulations and it would be interesting to determine if there is a "recency" effect associated with simulations. Because they are "newer," are perceptions of effectiveness moderated by one's perceptions of the simulations novelty?

Second, there is an opportunity to further explore the drivers of why simulations were not viewed as being more effective than case studies, service learning, and in-class discussions. These findings were interesting because faculty agreed or strongly agreed that simulations helped in areas like knowledge application, student experience, teamwork, and student engagement. Future research should further explore the comparison of experiential teaching methodologies. In particular, researchers could explore the effect of an exercises context (online, in-class, or working with a client) on perceptions of learning outcomes. Do students and faculty attribute any value to the "gaming" environment or are do they value any context that provides technical knowledge and decision making opportunities?

Lastly, research should explore the proliferation of simulations in business schools. As simulations become more popular, they will inevitably be used in multiple courses within colleges. Is there a saturation point where the "novelty" wears off and simulations become just "another" project? While gaming is part of today's student generation, will multiple simulations be viewed as multiple versions of the same video game? For example, if a student masters a particular football video game, do they get really excited with the notion of mastering another football video game? Additionally, research is needed to determine if there is a saturation point of simulations within a particular college or curriculum.

\section{CONCLUSIONS}

Today's learning environment mandates greater levels of student engagement, due mostly to shorter attention spans and the need for increased interaction and stimulation within a structured environment. Such a learning environment applies to students in most college curricula, including undergraduate business students. This study addressed three research questions, conclusions of which are as follows:

1. Do faculty members agree with student evaluations of business simulation games as effective learning tools?

Results of this study indicate that marketing faculty and management faculty perceive business simulation games as useful learning tools for their students, a perception that appears to be compatible with that of students, who perceive such tools as leading to an elevated learning experience.

2. Do faculty members believe simulations are more effective than traditional experiential methodologies?

While marketing and management faculty perceive business simulation games as useful for student engagement and learning, they do not distinguish such tools as superior to other traditional approaches, such as case studies, service learning, or class discussions.

3. What value do faculty members receive from the incorporation of simulations in their teaching methods?

Results of this study suggest that marketing and management faculty view business simulation tools as providing a structure around which delivery of course material and content may be delivered with greater effectiveness, as compared with other methodologies. Interestingly, the same faculty group feels that simulation tools do not contribute toward greater pedagogical creativity, nor do they seem to lead to a tighter connection with their students. 
The principal contribution of this study is an expanded insight into marketing and management faculty perceptions about the use of simulation tools for undergraduate business courses. Both groups perceive business simulations as useful teaching tools for their undergraduate courses; however, neither group views business simulations as offering learning opportunities that are superior to other traditional methodologies, such as case studies, service learning, or in-class discussions. Given that, relative to other methodologies, the use of simulation tools is a fairly recent phenomenon, future research should account for the likelihood that, over time, simulation tools will become more commonplace in undergraduate business courses.

\section{AUTHOR INFORMATION}

John R. Tanner is a Professor in the Department of Business Systems, Analysis, and Technology at the University of Louisiana at Lafayette, and is the Melvin R. Boesch/Regents Professor of Business Administration. Dr. Tanner has published in such journals as Omega, Journal of Management Information Systems, Information and Management, Journal of Computer Information Systems, Journal of Informatics Education Research, and Journal of Education for Business. E-mail: jrt4671@ louisiana.edu. Corresponding author.

Geoffrey T. Stewart is an Assistant Professor of Marketing at the University of Louisiana. Dr. Stewart holds a Ph.D. in Marketing from the University of Tennessee, as well as BS and MBA degrees from the University of Louisiana. His current research focuses on business relationship development, public-private partnerships, and supply chain disruptions. Dr. Stewart's previous publications have appeared in the International Journal of Physical Distribution and Logistics Management, Marketing Management Journal, Research in Higher Education Journal and Equal Opportunities International. E-mail: gts2138@louisiana.edu.

Michael W. Totaro is an Assistant Professor in the Department of Business Systems, Analysis, and Technology and the University of Louisiana at Lafayette, teaching courses in database systems, business intelligence, computer networks, and systems analysis. Dr. Totaro has published in such journals as International Journal of Education Research, Journal of Computer Information Systems, Journal of Informatics Education Research, Journal of Applied Business Research, and Review of Business Information Systems. E-mail: mwt3774@louisiana.edu.

Melissa Hargrave is a McNair Scholar at the University of Louisiana at Lafayette. She completed her B.S.B.A. degree with a major in Economics. E-mail: mel_noah@yahoo.com.

\section{REFERENCES}

1. Alreck, P., \& Settle, R. (2004). The Survey Research Handbook, 3rd Edition, Homewood, IL: Irwin, 36.

2. Anderson, J. (2003). The relationship between student perceptions of team dynamics and simulation game outcomes: An individual-level analysis. Journal of Education for Business, 81(2), 85-89.

3. Anselmi, K., \& Frankel, R. (2004). Modular experiential learning for business-to-business marketing courses. Journal of Education for Business, 79(3), 169-175.

4. $\quad$ Buzzetto-More, N., \& Mitchell, B. (2009). Student performance and perceptions in a web-based competitive computer simulation. Interdisciplinary Journal of E-Learning and Learning Objects, 5, 73-89.

5. Cohen, K., \& Rhenman, E. (1961). The role of management games in education and research. Management Science, 7(2), 131-166.

6. de Freitas, S. I. (2006). Using games and simulations for supporting learning. Learning, Media \& Technology, 31(4), 343-358.

7. Goorha, P., \& Mohan, V. (2010). Understanding learning preferences in the business school curriculum. Journal of Education for Business, 85(3), 145-152.

8. Gorrell, J. (1992). Outcomes of using computer simulations. Journal of Research on Computing in Education, 24(3), 359-366.

9. Jager, W. (2007). The four p's in social simulation, a perspective on how marketing could benefit from the use of social simulation. Journal of Business Research, 60, 868-875.

10. Lainema, T., \& Lainema, K. (2007). Advancing acquisition of business know-how: Critical learning elements. Journal of Research on Technology in Education, 40(2), 183-198. 
11. Lamont, L. (2001). Enhancing student and team learning with interactive marketing simulations. Marketing Education Review, 11(1), 45-55.

12. Léger, P.-M. (2006). Using a simulation game approach to teach enterprise resource planning concepts. Journal of Information Systems Education, 17 (4), 441-447.

13. Li, T., Greenberg, B., \& Nicholls, J. (2007). Teaching experiential learning: Adoption of an innovative course in an MBA marketing curriculum. Journal of Marketing Education, 29(1), 25-33.

14. Maher, J., \& Hughner, R. (2005). Experiential marketing projects: Student perceptions of live case and simulation methods. Journal for Advancement of Marketing Education, 7, 1-10.

15. McCarthy, P., \& McCarthy, H. (2006). When case studies are not enough: Integrating experiential learning into business curricula. Journal of Education for Business, 81(4), 201-204.

16. Michlitsch, J., \& Sidle, M. (2002). Assessing student learning outcomes: A comparative study of techniques used in business school disciplines. Journal of Education for Business, 77(3), 125-130.

17. Raymond, M., \& McNabb, D. (1993). Preparing graduates for the workforce: The role of business education. Journal of Education for Business, 68(4), 202-206.

18. Romme, A. \& Georges, L. (2003). Learning outcomes of microworlds for management education. Management Learning 34(1), 51-61.

19. Tompson, George H. (1995). Using computer simulations for group projects in business school education. Journal of Education for Business, 71(2), 97-101.

20. Tonks, David G. (2005). The processing and pedagogy of marketing simulations. The Marketing Review, 5, 371-382.

21. Wilson, M., \& Gerber, L. (2008). How generational theory can improve teaching: Strategies for working with the "millennials." Currents in Teaching and Learning 1(1), 29-44.

22. Xu, Yang, \& Yang, Yi. (2010). Student learning in business simulation: An empirical investigation. Journal of Education for Business, 85, 223-228. 


\section{APPENDIX: MEASUREMENT ITEMS BY THEME}

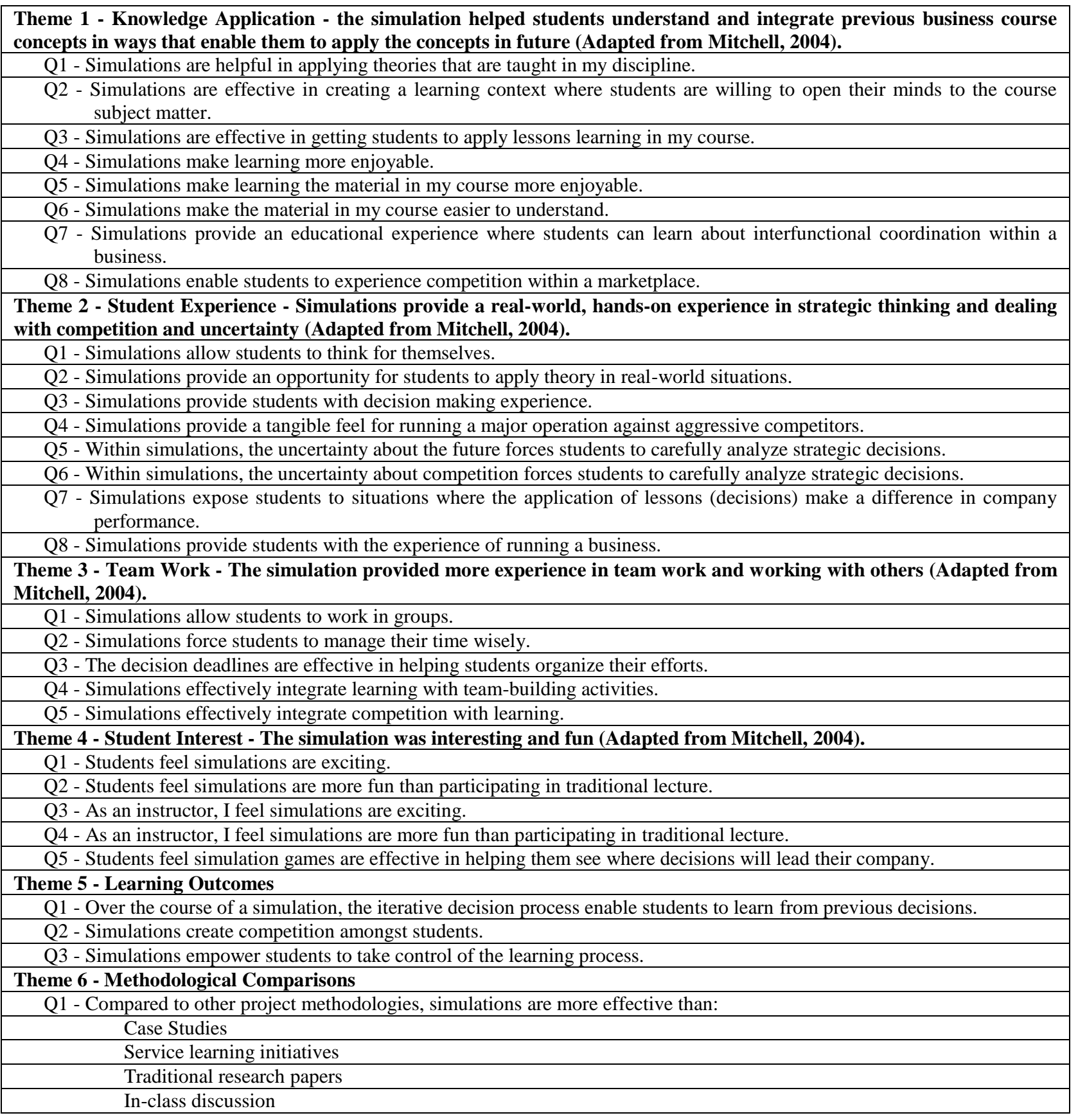




\begin{tabular}{|l|}
\hline Theme 7 - Benefits to the instructor \\
\hline Q1 - Simulations establish a context for class discussions. \\
\hline Q2 - Given the structure of the game, simulations reduce my preparation time. \\
\hline Q3 - Simulations improve the learning environment of my classroom. \\
\hline Q4 - Simulations effectively engage the minds of my students. \\
\hline Q5 - Simulations positively influence the engagement of students on other course-related activities. \\
\hline Q6 - I feel simulation games make me a more effective instructor. \\
\hline Q7 - simulation games have inspired me to be more creative in class. \\
\hline Q8 - Simulation games help me connect with my students. \\
\hline Q9 - I can structure my course outline around the simulation schedule. \\
\hline Q10 - I am able to easily integrate the simulation schedule into my course outline. \\
\hline
\end{tabular}

\section{NOTES}

